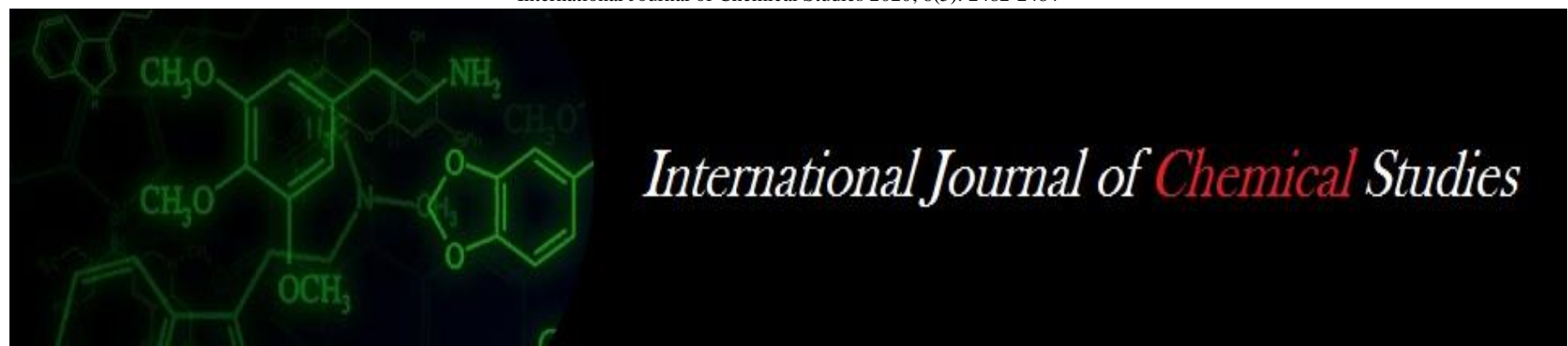

P-ISSN: 2349-8528

E-ISSN: 2321-4902

www.chemijournal.com

IJCS 2020; 8(5): 2482-2484

(C) 2020 IJCS

Received: 18-07-2020

Accepted: 21-08-2020

Rohit Kumar Kharra

Department of Horticulture,

H.N.B. Garhwal University,

Srinagar (Garhwal),

Uttarakhand, India

DK Rana

Department of Horticulture,

H.N.B. Garhwal University,

Srinagar (Garhwal),

Uttarakhand, India

Manish Kumar

Department of Horticulture, H.N.B. Garhwal University,

Srinagar (Garhwal),

Uttarakhand, India

Harendra Kumar

Department of Horticulture, H.N.B. Garhwal University, Srinagar (Garhwal),

Uttarakhand, India

Govind Ram Choudhary

Department of Horticulture,

H.N.B. Garhwal University,

Srinagar (Garhwal),

Uttarakhand, India
Corresponding Author: Rohit Kumar Kharra

Department of Horticulture, H.N.B. Garhwal University,

Srinagar (Garhwal),

Uttarakhand, India

\section{Impact of planting distance and bio-fertilizers on growth and yield attributes of turnip (Brassica rapa L.) cv. Pusa Sweti under Garhwal hills}

\author{
Rohit Kumar Kharra, DK Rana, Manish Kumar, Harendra Kumar and \\ Govind Ram Choudhary
}

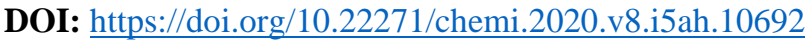

\begin{abstract}
A field experiment was conducted during Rabi season 2017-18 at Horticultural Research Centre, Chauras Campus, H.N.B. Garhwal University, Srinagar (Garhwal), Uttarakhand to find out the combined effect of planting distance and bio-fertilizers on growth and yield of turnip under sub-tropical condition of Garhwal Himalaya. Nine treatment combinations were investigated. Treatments comprises three different planting distance: $S_{1}(10 \mathrm{~cm} \times 40 \mathrm{~cm}), S_{2}(15 \mathrm{~cm} \times 40 \mathrm{~cm})$ and $\left.S_{3}(20 \mathrm{~cm} \times 40 \mathrm{~cm})\right)$, three biofertilizer: $\mathrm{B}_{1}$ (Azotobacter), $\mathrm{B}_{2}$ (Azospirillum) and $\mathrm{B}_{3}$ (Control) in Factorial Randomized Block Design with three replications. Results revealed that the planting distance and biofertilizers significantly influenced the growth and yield attributing characteristics. The treatment combination $\mathrm{S}_{3} \mathrm{~B}_{1}(40 \mathrm{~cm} \times 20 \mathrm{~cm}$ with Azotobactor) was found superior all other treatments in relation to growth and yield attributes of turnip.
\end{abstract}

Keywords: Growth and yield attributes, biofertilizers and planting distance

\section{Introduction}

Turnip (Brassica rapa L.) is a winter vegetable and herbaceous biennial in nature, comes under the family of brassicaceae. It is mainly grown for the hypocotyls and the swollen upper part of the root and lower part of the stem. It has a crisp white flesh and a zesty mustard-like flavor and a rapidly maturing crop. Its root is called underground modified root, which is napiform in shape. The stem is short at vegetative stage but elongated at the reproductive stage. It is well established in fertile and medium to heavy well drained soils are best suited to grow. Turnip can be grown in slightly acidic to saline soils. However, the optimum soil $\mathrm{pH}$ range is 6.0-7.0 (Choudhary, 2015) ${ }^{[6]}$. Determining spacing is one of the most important requirements of farming planning to realize maximum yield with an optimum quality. The biofertilizers are organic in origin and thus are absolutely safe. Therefore, it is essential to adopt a strategy of integrated nutrient management using combination of chemical fertilizers, organic manures and bio-fertilizers so as to minimize the cost of production and to maintain biological productivity of soils, particularly because the farmers are reluctant to adopt recommended fertilizer doses due to the high cost and risk of crop failure on account of aberrant weather conditions. The interactive advantages of combining inorganic and organic sources of nutrient generally provide superior status to use of each component separately. The judicious application of organic and inorganic fertilizers have maintained long term soil fertility and sustained higher level of productivity.

\section{Materials and Methods}

The experiment was conducted at Horticultural Research Centre, Chauras Campus, H.N.B. Garhwal University, Srinagar (Garhwal), Uttarakhand. Geographically, the Horticultural Research Centre is situated in Alaknanda valley which lies between $78^{0} 47^{\prime} 30^{\prime \prime}$ E longitude and $30^{\circ} 13^{\prime} 0^{\prime}$ ' $\mathrm{N}$ latitude, right in the heart of Garhwal region at an elevation $540 \mathrm{~m}$ above MSL, in the lesser Himalayan region. The climate of Horticultural Research Centre is humid subtropical with minimum and maximum temperature ranging between $7.5{ }^{\circ} \mathrm{C}$ to $25.8{ }^{\circ} \mathrm{C}$ and 17.7 ${ }^{0} \mathrm{C}$ to $40{ }^{\circ} \mathrm{C}$, respectively during experimentation. The experiment was laid out in Randomized Block Design (RBD) with three replication and experiment comprised of 9 Treatment 
combinations with three different planting distance: $S_{1}(10 \mathrm{~cm}$ x $40 \mathrm{~cm}), S_{2}(15 \mathrm{~cm} \mathrm{x} 40 \mathrm{~cm})$ and $\left.S_{3}(20 \mathrm{~cm} \mathrm{x} 40 \mathrm{~cm})\right)$, three biofertilizer: $\mathrm{B}_{1}$ (Azotobacter), $\mathrm{B}_{2}$ (Azospirillum) and $\mathrm{B}_{3}$ (Control). Recommended package of practices were followed for weeding, fertilizer application and crop protection management to grow the crop. All the parameters were collected from five randomly selected plants of each treatment. Least significant difference at 5\% level was used for finding the significant differences among the treatment means. The data obtained from selected plants were subjected to analysis of variance Panse and Sukhamate (1961) ${ }^{[10]}$.

\section{Results and Discussion \\ Effect of plant spacing}

Widders and Price (1989) ${ }^{[13]}$ defined spacing as the distance between the plants in the row and between the rows of sowing crops. Plant density for turnip is an important criterion for attaining maximum yield. Densely sowing crop obstructs the proper growth and development with hampering the basic requirement of plant growth. On the other hand wider spacing ensure the basic requirements but decrease the total number of plants as well as total yield. Yield may be increased by $25 \%$ by using optimum spacing Bansal et al. (1995) ${ }^{[1]}$. Different plant spacing influenced the various characters. In case of different growth and development parameters viz. plant height $(31.52 \& 37.68 \mathrm{~cm})$, number of leaves per plant $(11.77 \&$ $16.62)$, diameter of root $(81.72 \mathrm{~mm})$, total plant weight (304.62), fresh and dry leaf weight (153.07 \& 10.61), fresh and dry root (138.16 \& 18.96), yield per plot $(7.16 \mathrm{~kg})$ and TSS $\left(9.04{ }^{\circ}\right.$ Brix) were found superior under $\mathrm{S}_{3}(40 \mathrm{~cm} \times 20$ $\mathrm{cm})$ followed by $S_{1}(40 \mathrm{~cm} \times 10 \mathrm{~cm})$ and $S_{2}(40 \mathrm{~cm} \times 15 \mathrm{~cm})$. The wider spacing favoured the more values due to lesser competition for moisture, light and nutrients. In very dense stands, both inter- plant and intra- plant competition for moisture, light and nutrition was sufficiently served to reduce height of plant. On the other hand, widest spacing gave most favorable conditions. The results are in conformity with findings of Bilekudari et al. (2005) ${ }^{[3]}$, Dod et al. (2010) ${ }^{[8]}$, Pervez et al. (2004) ${ }^{[11]}$.

\section{Effect of bio-fertilizer}

Plant nutrients by bio-fertilizers (Azospirillum) as evidenced by the increase in uptake of N, P and K Subbiah et al. (1983) and also due to its favorable effect on several physical properties of the soil. Bio-fertilizer influenced the various characters. In case of different growth and development parameters viz. plant height $(31.40 \& 37.37 \mathrm{~cm}) 30 \& 45$ DAS, number of leaves per plant (12.58 \& 16.74) $30 \& 45$ DAS, diameter of root $(76.30 \mathrm{~mm})$, total plant weight $(307.62$ $\mathrm{g})$, fresh and dry leaf weight $(147.0 \& 9.47 \mathrm{~g})$ fresh and dry root weight (135.88 \& $18.48 \mathrm{~g})$, yield per plot $(8.08 \mathrm{~kg})$ and TSS $\left(8.82{ }^{\circ}\right.$ Brix) were found superior under $\mathrm{B}_{1}$ (Azotobacter) followed by $\mathrm{B}_{2}$ (Azospirrilum) and $\mathrm{B}_{0}$ (control). The increase in growth parameters because of certain growth promoting substances secreted by the bio-fertilizers (Azotobactor) inoculants, which in turn might have lead to good root development, better water absorption, and high uptake of nutrients from the soil body, which ultimately enhance number of leaves per plant. Similar observations have been reported by Chattoo et al. (1997) ${ }^{[5]}$ in knol-khol and Chatterjee et al. (2005) ${ }^{[4]}$ in sprouting broccoli. The root diameter of turnip is increases with the increases the photosynthetic activity and higher nutrients uptake, that results the increasing the root diameter. Similar findings have been reported by Manivannan and Singh (2004) [9] in Broccoli, Bhusan et al. (2010) ${ }^{[2]}$ and Divya (2010) ${ }^{[7]}$ in Knolkhol. Improves the soil condition, soil bulk density, aeration and enhance the availability of macro and micro nutrients and photosynthetic activity in plant which ultimately increases the total plant weight Bhusan et al. (2010) ${ }^{[2]}$.

Table 1: Effect of planting distance and bio-fertilizers on growth and yield attributes of turnip

\begin{tabular}{|c|c|c|c|c|c|c|c|c|}
\hline \multirow{2}{*}{\begin{tabular}{|c|} 
Treatment \\
Effect of planting distance \\
\end{tabular}} & \multicolumn{2}{|c|}{ Plant height (cm) } & \multicolumn{2}{|c|}{ Number of leaves } & \multirow[b]{2}{*}{ Root diameter (mm) } & \multirow{2}{*}{ Whole plant weight $(g)$} & \multirow{2}{*}{ Fresh leaf weight $(g)$} & \multirow[b]{2}{*}{ Dry leaf weight (g) } \\
\hline & 30 DAS & 45 DAS & 30 DAS & 45 DAS & & & & \\
\hline $\mathrm{S}_{1}$ & 24.35 & 37.66 & 10.6 & 15.56 & 115.3 & 290.47 & 115.3 & 8.47 \\
\hline $\mathrm{S}_{2}$ & 27.46 & 29.33 & 10.87 & 14.58 & 153.7 & 304.62 & 153.7 & 8.01 \\
\hline $\mathrm{S}_{3}$ & 31.52 & 37.68 & 11.77 & 16.62 & 150.5 & 292.24 & 150.5 & 10.61 \\
\hline $\operatorname{SEm}( \pm)$ & 0.78 & 0.50 & 0.27 & 0.50 & 1.47 & 0.50 & 0.48 & 0.26 \\
\hline $\mathrm{CD}(5 \%)$ & 2.36 & 1.52 & 0.83 & 1.51 & 1.86 & 1.52 & 1.47 & 0.69 \\
\hline \multicolumn{8}{|c|}{ Effect of bio-fertilizer } & \\
\hline $\mathrm{B}_{1}$ & 26.49 & 30.93 & 10.76 & 16.74 & 67.61 & 295.52 & 138.4 & 9.0 \\
\hline $\mathrm{B}_{2}$ & 25.45 & 36.37 & 9.9 & 15.76 & 65.87 & 307.05 & 147.0 & 9.47 \\
\hline $\mathrm{B}_{0}$ & 31.40 & 37.37 & 12.58 & 14.26 & 76.30 & 284.77 & 134.1 & 8.61 \\
\hline $\operatorname{SEm}( \pm)$ & 0.78 & 0.50 & 0.27 & 0.50 & 0.61 & 0.50 & 0.48 & 0.26 \\
\hline $\mathrm{CD}(5 \%)$ & 2.36 & 1.52 & 0.83 & 1.51 & 1.86 & 1.52 & 1.47 & 0.79 \\
\hline
\end{tabular}

Table 2: Effect of planting distance and bio-fertilizers on yield attributes and TSS of Turnip

\begin{tabular}{|c|c|c|c|c|}
\hline \multicolumn{5}{|c|}{ Effect of spacing } \\
\hline Treatment & Fresh root weight (g) & Dry root weight (g) & Yield per plot (kg) & TSS ('Brix) \\
\hline $\mathrm{S}_{1}$ & 138.16 & 16.41 & 5.92 & 7.66 \\
\hline $\mathrm{S}_{2}$ & 101.60 & 15.88 & 5.62 & 9.04 \\
\hline $\mathrm{S}_{3}$ & 126.43 & 18.96 & 7.16 & 7.43 \\
\hline $\mathrm{SEm}( \pm)$ & 0.91 & 0.34 & 0.86 & 0.40 \\
\hline $\mathrm{CD}(5 \%)$ & 2.57 & 1.03 & 2.60 & 1.22 \\
\hline \multicolumn{5}{|l|}{ Effect of bio-fertilizer } \\
\hline $\mathrm{B}_{1}$ & 135.88 & 16.28 & 4.11 & 8.82 \\
\hline $\mathrm{B}_{2}$ & 119.77 & 18.48 & 6.51 & 8.27 \\
\hline $\mathrm{B}_{0}$ & 110.54 & 16.49 & 8.08 & 7.04 \\
\hline $\mathrm{SEm}( \pm)$ & 0.34 & 0.34 & 0.86 & 0.40 \\
\hline $\mathrm{CD}(5 \%)$ & 1.03 & 1.03 & 2.93 & 1.22 \\
\hline
\end{tabular}




\section{References}

1. Bansal GL, Rana MC, Upadhyay RG. Response of grain amaranth (Amaranthus hypochondriacus) to plant density. Indian Journal of Agriculture Science 1995;65(11):818-820.

2. Bhusan A, Sharma AK, Sharma JP. Integrated nutrient management in knol-khol under Jammu and Kashmir condition. Journal Research, Sher e Kashmir University of Agricultural Sciences, and Technology 2010;9(2):240243.

3. Bilekudari MK, Deshpande VK, Shekhargouda M. Effect of spacing and fertilizer levels on growth, seed yield and quality of radish. Karnataka Journal of Agricultural Sciences 2005;18(2):338-342.

4. Chaterjee B, Ghanti P, Thapa, Tripathy P. Effect of organic nutrition in sprouting broccoli (Brassica oleraceae var. Italica Plenck). Vegetable Science 2005;33(1):51-54.

5. Chattoo MA, Gandroo MY, Zargeer MY. Effect of Azospirillum and Azotobacter on growth, yield and quality of knol-khol (Brassica oleracea var. gongylodes). Vegetable Science 1997;24(1):16-19.

6. Choudhary BR. Vegetable. Kalyani Publishers 2015, 99103.

7. Divya CV. Studies on organic production techniques in Knolkhol (Brassica oleracea var. gongylodes L.). M.Sc. Thesis Submitted to University of Agricultural Science, Dharwad, Karnataka (India) 2010.

8. Dod VN, Java Giri, Deshmukh M. Effect of plant spacings on seed yield and quality of radish. Annals of Plant Physiology 2010;24(1):110-111.

9. Manivannan MI, Singh JP. Effect of bio-fertilizers on the growth and yield of sprouting broccoli (Brassica oleracea var. Italica Plenck) under Allahabad agroclimatic conditions. Bioved 2004;15(1/2):33-36.

10. Panse VG, Sukhatme PV. Statistical Methods for Agriculture Workers. II ed. ICAR New Delhi 1961.

11. Pervez MA, Ayub Saleem BA, Virk NA, Nasir Mahmood. Effect of nitrogen levels and spacing on growth and yield of radish. (Raphanus sativus L.). International Journal of Agriculture and Biology 2004;6(3):504-506.

12. Subbaiah K, Sundararajan S, Muthuswami S. Effect of varying levels of organic and inorganic fertilizers on yield and nutrient uptake in brinjal. Indian Horticulture 1983;31:287-290.

13. Widders, Price. Effect of planting density on root crops, Journal of the American Society for Horticultural Science ISSN: 0003-1062 1989. 